\title{
Synthesis of $\mathrm{LiNiO}_{2}$ by two-step solid-state method
}

\author{
Shuiping Li ${ }^{1,2, *}$, Qisheng Wu ${ }^{1}$, Chun Zhang ${ }^{1}$, Huajun Zhu ${ }^{1}$, Changsen Zhang ${ }^{1}$, \\ XIN WANG ${ }^{1}$, CANCAN KONG ${ }^{1}$ \\ ${ }^{1}$ School of Materials Science and Engineering, Yancheng Institute of Technology, Jiangsu Yancheng, 224051, P.R. China \\ ${ }^{2}$ Institute of Cement Science and New Building Materials, China Building Materials Academy, Beijing, 10024, P.R. China \\ $\mathrm{LiNiO}_{2}$ was prepared through two-step solid-state reaction by mechanochemical method and heat treatment, using LiOH \\ $\left(\mathrm{Li}_{2} \mathrm{CO}_{3}\right)$ and $\mathrm{Ni}(\mathrm{OH})_{2}$ as starting materials. The influence of grinding speed and time, heat treatment time, and starting ma- \\ terials on the structure of $\mathrm{LiNiO}_{2}$ was studied. The as-milled samples and products were characterized by scanning electron \\ microscope (SEM) and X-ray diffraction (XRD). The results show that uniform as-milled samples can be obtained at grinding \\ speed of $580 \mathrm{rpm}$ for $0.5 \mathrm{~h}$, using $\mathrm{LiOH}$ and $\mathrm{Ni}(\mathrm{OH})_{2}$ as raw materials. Perfect crystal $\mathrm{LiNiO}_{2}$ has been prepared by calcining \\ the as-milled samples at $700{ }^{\circ} \mathrm{C}$ for $15 \mathrm{~h}$. Composite material powders consisting of $\mathrm{Li}_{2} \mathrm{Ni}_{8} \mathrm{O}_{10}$ and $\mathrm{LiNiO}_{2}$ have been obtained \\ using $\mathrm{Li}_{2} \mathrm{CO}_{3}$ as lithium source.
}

Keywords: grinding; lithium; solid-state method; mechanochemistry

\section{Introduction}

Lithium ion battery is a new kind of "green" chemical cell. Many studies have been focused on the research and development of cathode materials for Li-ion batteries. The development of cathode materials with high capacity, good chargedischarge properties, highly reversible embedded reaction, thermal stability and stabilization of electrolyte is critical for Li-ion batteries. The application of $\mathrm{LiCoO}_{2}$, which is the most common commercial lithium ion battery cathode material, is restricted due to the toxicity and scarcity of Co. $\mathrm{LiNiO}_{2}$, which shows a layered structure, low cost and is environment friendly, is widely used as the material substituting $\mathrm{LiCoO}_{2}$.

The general synthesis methods of $\mathrm{LiNiO}_{2}$ cathode materials include high temperature solid state method [1-5], combustion method [6] and molten salt method [7]. However, these methods are restricted owing to the high temperature, long time, and low uniformity of the products. Many methods for preparation of new materials, such as emulsion method [8], ion exchange method [9], thin film

*E-mail: lishuiping2002@hotmail.com processes [10], sol-gel method [11], voltage prediction method [12], precipitation method [13], hydrolysis of metal alkoxides [14], and refluxing method using acetic acid [15], have been tried safely and economically to synthesize $\mathrm{LiNiO}_{2}$ cathode materials. However, the results are not enough satisfactory to the researchers because of the complex fabrication process and low electrochemical performance of the product.

Mechanochemical technology, which is a wellknown method for the preparation of nanomaterials, super thin powders and alloys, is extremely useful for promoting intimate mixing by pulverization of the starting materials during high-energy milling [16]. On the one hand, the impact of high-energy forces originating from the pulverization enhances diffusion of the starting materials and consequently, promotes chemical reactions resulting in metastable structures [16, 17]. On the other hand, the high-energy milling action has been reported to generate nanostructured as well as metastable phases of various compounds [17]. Therefore, these advantages could be very useful for synthesizing $\mathrm{LiNiO}_{2}$ at low temperatures.

In the present work, $\mathrm{LiNiO}_{2}$ was prepared through two-step solid-state reaction by 
mechanochemical method and heat treatment at low temperature. The effect of starting materials, grinding speed and time as well as heat treatment time on the structure of $\mathrm{LiNiO}_{2}$ was studied.

\section{Experimental}

$\mathrm{LiOH} \cdot \mathrm{H}_{2} \mathrm{O}, \quad \mathrm{Ni}(\mathrm{OH})_{2} \cdot \mathrm{H}_{2} \mathrm{O}$ and $\mathrm{Li}_{2} \mathrm{CO}_{3}$ $(99.9 \%)$ were purchased from Shanghai Runjie Chemical reagent Co., Ltd., Shanghai, China. In general, certain starting materials containing $\mathrm{LiOH} \cdot \mathrm{H}_{2} \mathrm{O}$ (or $\mathrm{Li}_{2} \mathrm{CO}_{3}$ ) and $\mathrm{Ni}(\mathrm{OH})_{2} \cdot \mathrm{H}_{2} \mathrm{O}$ with a molar ratio of $\mathrm{Ni} / \mathrm{Li}$ equal to $1: 1$ were first placed in an agate vial. Then, the vial was sealed and subjected to the milling process using the ND2 Mixer/Mill. The weight ratio of balls to powder of 8:1 was used as the mechanochemical process condition. Agate balls with diameters of $20 \mathrm{~nm}$, $10 \mathrm{~nm}$ and $6 \mathrm{~mm}$ were used in the process. Then, $\mathrm{LiNiO}_{2}$ was synthesized by calcining the as-milled samples for $5 \mathrm{~h}$ to $15 \mathrm{~h}$ in air at $700{ }^{\circ} \mathrm{C}$.

The as-milled samples of the final products were subjected to X-ray diffraction characterization (XRD, Y500, Fangyuan, China). The general XRD studies were performed in the $2 \theta$ range of $10^{\circ}$ to $90^{\circ}$ at $30 \mathrm{kV}$ and $20 \mathrm{~mA}$ at $0.09^{\circ}$ step size. A $\mathrm{Cu} \mathrm{X}$-ray tube was used as the radiation source in all experiments. Gravimetric/differential thermal analysis was also conducted on the starting materials using the simultaneous thermogravimetry-differential scanning calorimetry instrument (TG/DTA, STA449C, NETZSCH, Germany). A constant heating rate of $10{ }^{\circ} \mathrm{C} / \mathrm{min}$ was used for the samples subjected to TG/DTA analysis. The morphology of the powders was observed by scanning electron microscopy (SEM, QUANTA 200, FEI, the USA).

\section{Results and discussion}

The thermogravimetric behavior of the starting materials is shown in Fig. 1. In the TG-DTA curve of $\mathrm{LiOH} \cdot \mathrm{H}_{2} \mathrm{O}+\mathrm{Ni}(\mathrm{OH})_{2} \cdot \mathrm{H}_{2} \mathrm{O}$ (Fig. 1a), a drastic weight loss is observed at $87{ }^{\circ} \mathrm{C}$, which can be attributed to evaporation of the absorbed water. A subsequent weight loss appeared at $285^{\circ} \mathrm{C}$, which can be assigned to decomposition of the crystal water. The third weight loss, which can be observed at $425^{\circ} \mathrm{C}$, is attributed to decomposition of $\mathrm{Ni}(\mathrm{OH})_{2}$. The last weight loss is observed at $460{ }^{\circ} \mathrm{C}$, which can be assigned to the formation of $\mathrm{LiNiO}_{2}$. In the curve of $\mathrm{Li}_{2} \mathrm{CO}_{3}+\mathrm{Ni}(\mathrm{OH})_{2} \cdot \mathrm{H}_{2} \mathrm{O}$ (Fig. 1b), a weight loss is observed at $309{ }^{\circ} \mathrm{C}$, which can be attributed to decomposition of the water contained in the $\mathrm{Ni}(\mathrm{OH})_{2} \cdot \mathrm{H}_{2} \mathrm{O}$ crystal. A subsequent weight loss is continued beyond $1000{ }^{\circ} \mathrm{C}$. The observed weight loss can be attributed to the decomposition of $\mathrm{Li}_{2} \mathrm{CO}_{3}$ at $520{ }^{\circ} \mathrm{C}$, followed by the subsequent solid-state reaction between $\mathrm{Li}_{2} \mathrm{O}_{2}$ and $\mathrm{NiO}$ that continues to $1000^{\circ} \mathrm{C}$.
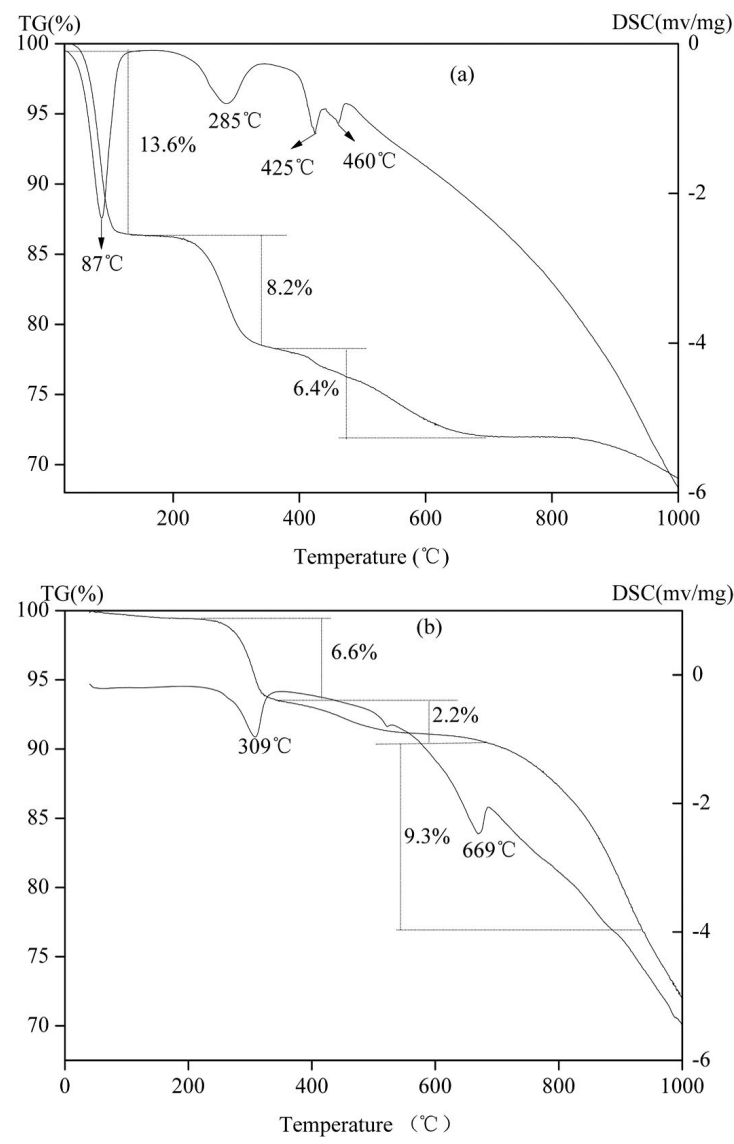

Fig. 1. TG-DTA curves of starting materials (a) $\mathrm{LiOH} \cdot \mathrm{H}_{2} \mathrm{O}+\mathrm{Ni}(\mathrm{OH})_{2} \cdot \mathrm{H}_{2} \mathrm{O}$
$\mathrm{Li}_{2} \mathrm{CO}_{3}+\mathrm{Ni}(\mathrm{OH})_{2} \cdot \mathrm{H}_{2} \mathrm{O}$

The XRD patterns of the products prepared by two-step solid-state reaction using different starting materials are shown in Fig. 2. 
In the XRD pattern of the product originating from $\mathrm{Li}_{2} \mathrm{CO}_{3}$ and $\mathrm{Ni}(\mathrm{OH})_{2} \cdot \mathrm{H}_{2} \mathrm{O}$, most of diffraction peaks can be attributed to the characteristic peaks of $\mathrm{Li}_{2} \mathrm{Ni}_{8} \mathrm{O}_{10}$. All diffraction peaks in the XRD pattern, originating from $\mathrm{LiOH} \cdot \mathrm{H}_{2} \mathrm{O}+\mathrm{Ni}(\mathrm{OH})_{2} \cdot \mathrm{H}_{2} \mathrm{O}$, can be assigned to the characteristic peaks of $\mathrm{LiNiO}_{2}$, which implies a well-crystallized nature of the final products. In the mechanochemical process, $\mathrm{LiOH} \cdot \mathrm{H}_{2} \mathrm{O}$ decomposes easily into $\mathrm{Li}_{2} \mathrm{O}_{2}$ and $\mathrm{H}_{2} \mathrm{O}$. The $\mathrm{Li}_{2} \mathrm{O}_{2}$ can directly react with $\mathrm{NiO}$ which is the main decomposition product of $\mathrm{Ni}(\mathrm{OH})_{2} \cdot \mathrm{H}_{2} \mathrm{O}$ in the mechanochemical process, to generate $\mathrm{LiNiO}_{2}$. The obtained results demonstrate that $\mathrm{LiNiO}_{2}$ can be fabricated through two-step solid-state reaction method, using $\mathrm{LiOH} \cdot \mathrm{H}_{2} \mathrm{O}$ and $\mathrm{Ni}(\mathrm{OH})_{2} \cdot \mathrm{H}_{2} \mathrm{O}$ as starting materials. The decomposition enthalpy of $\mathrm{Li}_{2} \mathrm{CO}_{3}$ is higher than that of $\mathrm{LiOH} \cdot \mathrm{H}_{2} \mathrm{O}$.

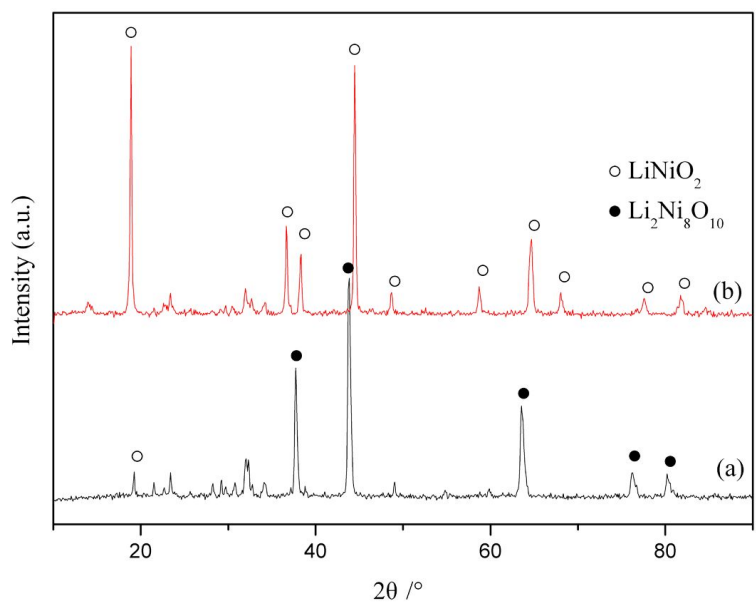

Fig. 2. XRD patterns of the products originating from (a) $\mathrm{Li}_{2} \mathrm{CO}_{3}+\mathrm{Ni}(\mathrm{OH})_{2} \cdot \mathrm{H}_{2} \mathrm{O}$ and (b) $\mathrm{LiOH} \cdot \mathrm{H}_{2} \mathrm{O}+\mathrm{Ni}(\mathrm{OH})_{2} \cdot \mathrm{H}_{2} \mathrm{O}$.

Fig. 3 shows the XRD patterns of the products prepared by mechanochemical process at different grinding speeds. The diffraction peaks in the curve of the sample prepared at $580 \mathrm{rpm}$ are attributed to the characteristic peaks of $\mathrm{LiNiO}_{2}$. However, the diffraction peaks in the curve of the sample prepared at $400 \mathrm{rpm}$ are mainly assigned to the characteristic peaks of $\mathrm{Li}_{2} \mathrm{Ni}_{8} \mathrm{O}_{10}$. These results indicate that $\mathrm{LiNiO}_{2}$ can be obtained through mechanochemical process conducted at $580 \mathrm{rpm}$, followed by heat treatment. The forces exerted on the material through grinding at $580 \mathrm{rpm}$ are more effective than those at $400 \mathrm{rpm}$, which improves diffusion of the components of the starting materials, thus promoting chemical reactions in heat treatment process [16].

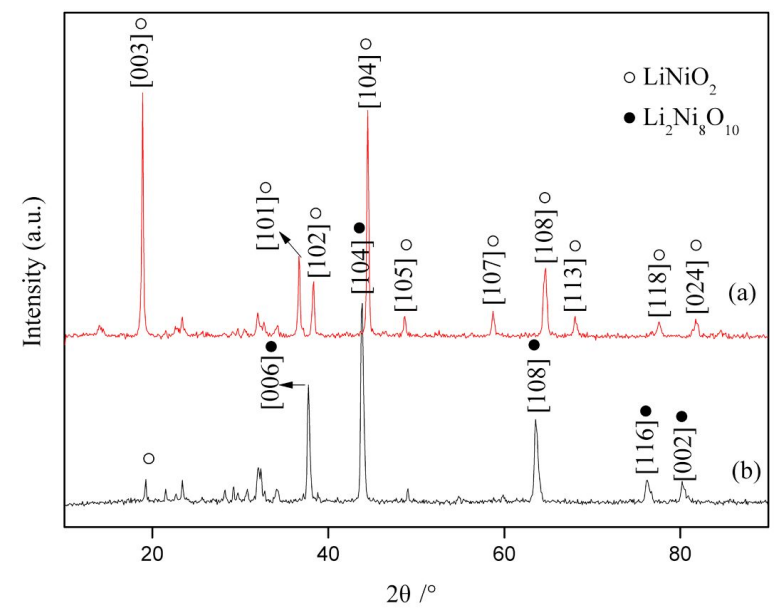

Fig. 3. XRD patterns of samples obtained at different grinding speeds (a) $580 \mathrm{rpm}$ and (b) $400 \mathrm{rpm}$.

Fig. 4 shows the XRD patterns of the products prepared at different times of mechanochemical process. In Fig. 4 it is observed that the diffraction peak at 2 -theta angle of $18.9^{\circ}$ starts to evolve at $0 \mathrm{~h}$ i.e. in the sample not subjected to the mechanochemical process. However, the characteristic peak of the $\left(\begin{array}{lll}0 & 0 & 3\end{array}\right)$ plane is lower than that of the (1 $\left.\begin{array}{lll}1 & 0\end{array}\right)$. This result implies that the (lllll $\left.0 \begin{array}{lll}0 & 3\end{array}\right)$ crystalline plane of $\mathrm{LiNiO}_{2}$ has not completely formed. For $0.5 \mathrm{~h}$ sample, distinct peaks have occurred implying a well-crystallized nature of the product. It indicates that $\mathrm{LiNiO}_{2}$ can be prepared through mechanochemical process lasting for $0.5 \mathrm{~h}$. The patterns of other samples show the characteristic peaks of $\mathrm{Li}_{2} \mathrm{Ni}_{8} \mathrm{O}_{10}$. Furthermore, the intensity ratio of (llll $\left.\begin{array}{lll}0 & 3\end{array}\right)$ to $\left(\begin{array}{lll}1 & 0 & 4\end{array}\right)$ peaks, $\mathrm{I}_{(003)} / \mathrm{I}_{(104)}$, is the most important index to evaluate the crystal structure of $\mathrm{LiNiO}_{2}$. When $\mathrm{I}_{(003)} / \mathrm{I}_{(104)}$ ratio is higher than 1 , the product shows a good crystal structure in which nickel and lithium ions are well ordered. In Fig. 4 it can be observed that the $\mathrm{I}_{(003)} / \mathrm{I}_{(104)}$ ratio of the product obtained at grinding time of $0.5 \mathrm{~h}$ is higher than 1. Therefore, the feasible time of mechanochemical process should be $0.5 \mathrm{~h}$. 

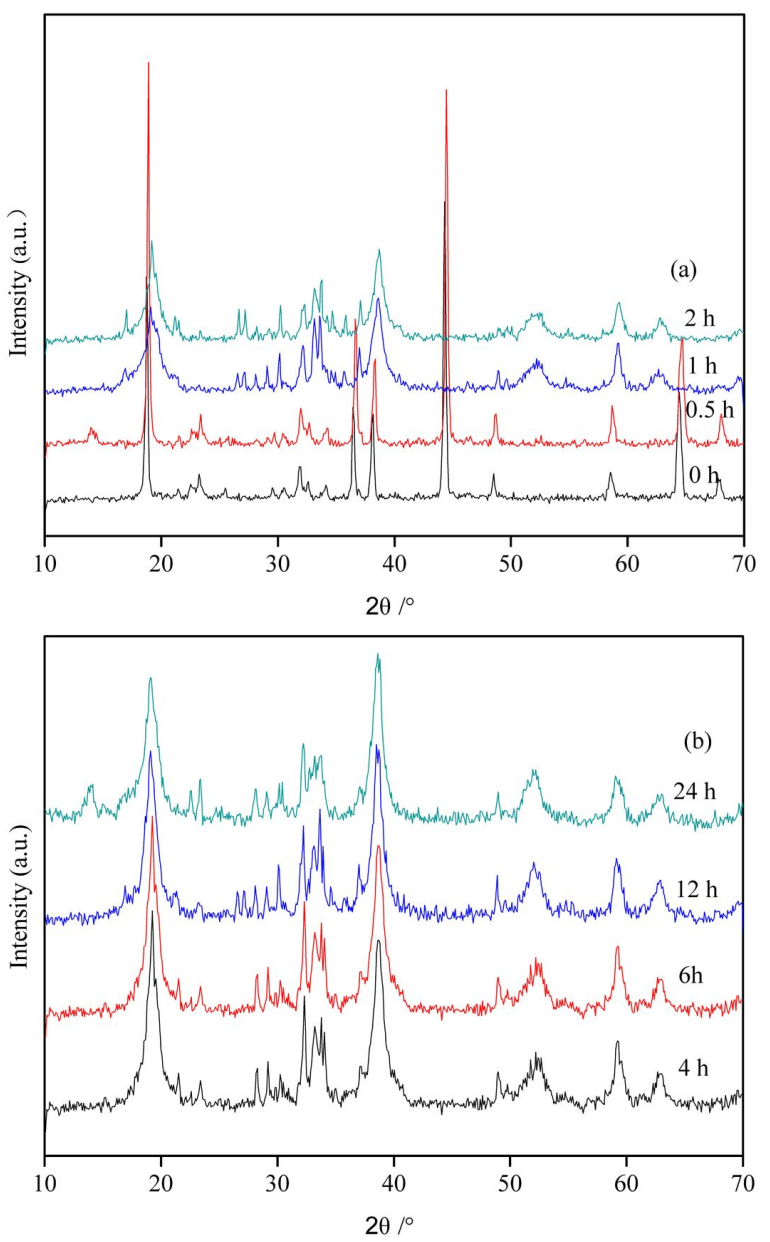

Fig. 4. XRD patterns of samples prepared at different grinding times (a) $0 \mathrm{~h}$ to $2 \mathrm{~h}$ samples and (b) $4 \mathrm{~h}$ to $24 \mathrm{~h}$ samples.

Fig. 5 shows the XRD patterns of the products prepared by heat treatment at $700{ }^{\circ} \mathrm{C}$ for different times. In Fig. 5 it is observed that a diffraction peak at 2-theta angle of $18.9^{\circ}$ starts to evolve for $5 \mathrm{~h}$ annealed sample. More peaks are observed for the sample obtained after heat treatment time of $10 \mathrm{~h}$. However, the main composition of the above two products is $\mathrm{Li}_{2} \mathrm{Ni}_{8} \mathrm{O}_{10}$. For $15 \mathrm{~h}$ annealed sample, distinct peaks, which can be assigned to the characteristic peaks of $\mathrm{LiNiO}_{2}$, can be observed. These results demonstrate that the optimal heat treatment time is $15 \mathrm{~h}$.

Incorporation of lithium ion into an electrode depends on the morphological structure of cathode materials [4]. Therefore, morphological study

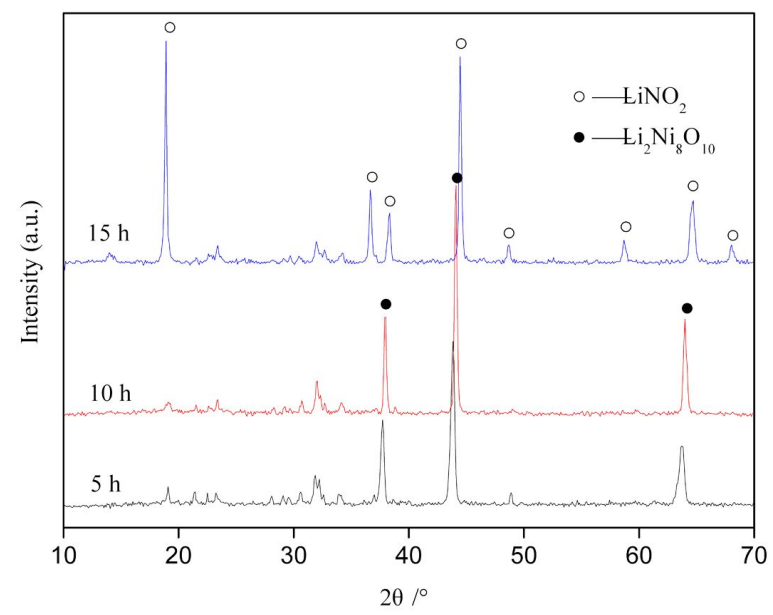

Fig. 5. XRD patterns of samples prepared by heat treatment for different time periods.

of cathode materials for Li-ion batteries is essential. Fig. 6 shows the scanning electron microscope images of the product prepared at grinding speed of $580 \mathrm{rpm}$ for $0.5 \mathrm{~h}$, followed by heat treatment at $700{ }^{\circ} \mathrm{C}$ for 15 . It is observed that the average diameter of $\mathrm{LiNiO}_{2}$ particles is about $15 \mu \mathrm{m}$. In addition, single $\mathrm{LiNiO}_{2}$ particle is a microsphere with a good mobility which consequently, improves the energy density of Li-ion batteries.

\section{Conclusions}

$\mathrm{LiNiO}_{2}$ was prepared through two-step solidstate reaction method. The products were characterized by XRD and SEM. The results indicated that $\mathrm{LiNiO}_{2}$ could be obtained by mechanochemical process at $580 \mathrm{rpm}$ for $0.5 \mathrm{~h}$, followed by heat treatment at $700{ }^{\circ} \mathrm{C}$ for $15 \mathrm{~h}$, using $\mathrm{LiOH} \cdot \mathrm{H}_{2} \mathrm{O}$ and $\mathrm{Ni}(\mathrm{OH})_{2} \cdot \mathrm{H}_{2} \mathrm{O}$ as starting materials. The mechanochemical process can promote chemical reactions between these two materials leading to the preparation of $\mathrm{LiNiO}_{2}$ which can be further improved by heat treatment process.

\section{Acknowledgements}

The authors gratefully acknowledge supports from the National Natural Science Foundation of China (51603179), the "Six Top Talents" Program of Jiangsu Province (2017GDZB-053 and 2016-XCL-070), the Joint Research Fund between the Collaborative Innovation Center for Ecological Building Materials and Environmental Protection Equipments 


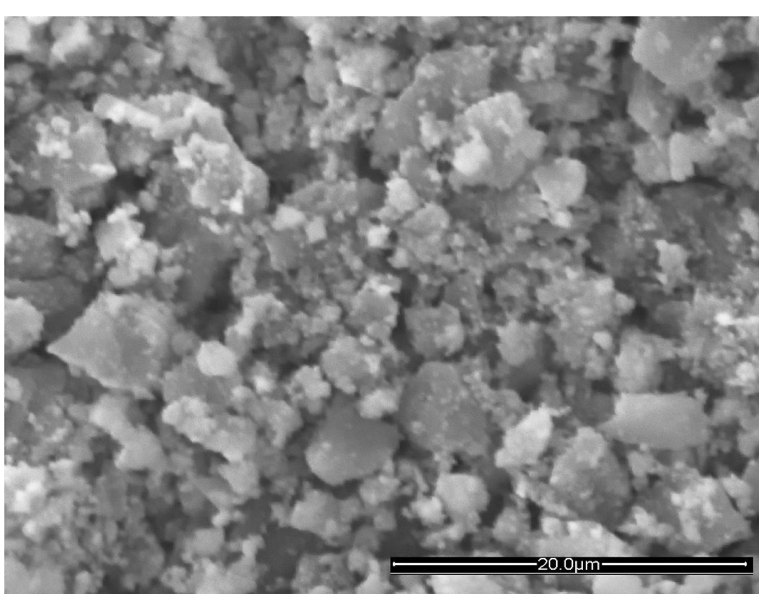

(a)

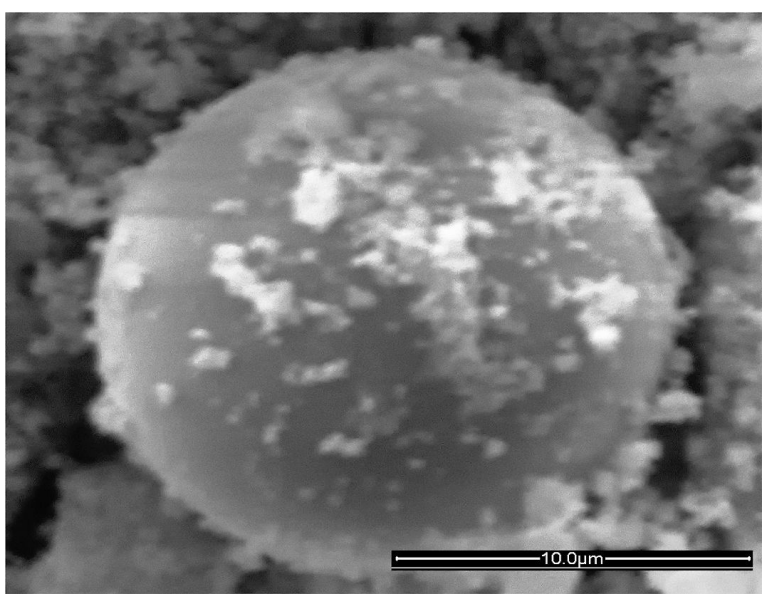

(b)

Fig. 6. SEM images of $\mathrm{LiNiO}_{2}$ prepared by two-step solid-state method at different magnifications (a) several particles and (b) a single particle.

of Jiangsu Province (CP201506), the Top-notch Academic Programs Project of Jiangsu Higher Education Institutions (PPZY2015A025).

\section{References}

[1] Zhong S.W., Zhao Y.J., Lian F., Li Y., Hu Y., LI P.Z., MeI J., LIU Q.G., Trans. Nonferrous Met. Soc. China, 16 (2006), 137.

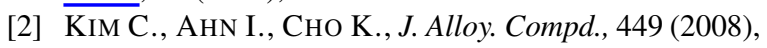
335.

[3] Hu G.R., Deng X.R., Peng Z.D., Rare Metal. Mater. Eng., 37 (2008), 1881.

[4] Sathiyamoorthi R., Shakkthivel P., RamalaKSHMI S., J. Power Sources, 171 (2007), 922.

[5] Cao J.F., Guo C., Zou H.M., J. Solid State Chem., 182 (2009), 555.

[6] Song M.Y., Kwon I., Shim S., Ceram. Int., 36 (2010), 1225.

[7] Ha H.W., Jeong K.H., Kim K., J. Power Sources, 161 (2006), 606.

[8] Kim B., Kim J., Kwon I., Ceram. Int., 33 (2007), 837.

[9] Sun Y.Z., WAN P.Y., PAN J.Q., Solid State Ionics, 177 (2006), 1173.

[10] Cho G.B., Choe H.J., Kim B.M., Mun H.J., NoH J.P., NAM T.H., J Alloy. Compd., 488 (2009), 17.

[11] Liu H.S., Yang Y., Zhang J.J., J. Power Sources, 173 (2007), 556.

[12] Yamaki J., Makidera M., KaWamura T., Egashira M., OKada S., J. Power Sources, 153 (2006), 245.

[13] Deng X.R., Hu G.R., Du K., Mater. Chem. Phys., 109 (2008), 469.

[14] Zhu C.G., Wei Y.J., Wang F.W., Initiators Pyrot., 4 (2008), 49.

[15] Kim J., Kim B.H., BAIK Y.H., J. Power Sources, 158 (2006), 641.

[16] Chang C.C., Kumta P.N., Mater. Sci. Eng. B-Adv., 116 (2005), 341.

[17] Hao W., Chen C., Jiang D.Y., Qiang L., J. Inorg. Mater., 33 (2007), 1093. 